\title{
LXIX.—Substituted Nitrogen Chlorides and Bromides derived from o- and $\mathrm{p}$-Acetotoluidide.
}

By F. D. Chattaway and K. J. P. Orton.

Вотн $o$ - and $p$-acetotoluidide, when treated with hypochlorous or hypobromous acid, yield nitrogen chlorides and bromides which readily undergo transformation into the isomeric substituted toluidides; these in their turn form nitrogen chlorides and bromides which pass into the disubstituted toluidides, the aminic hydrogen of the latter being again replaceable by chlorine or bromine thus :

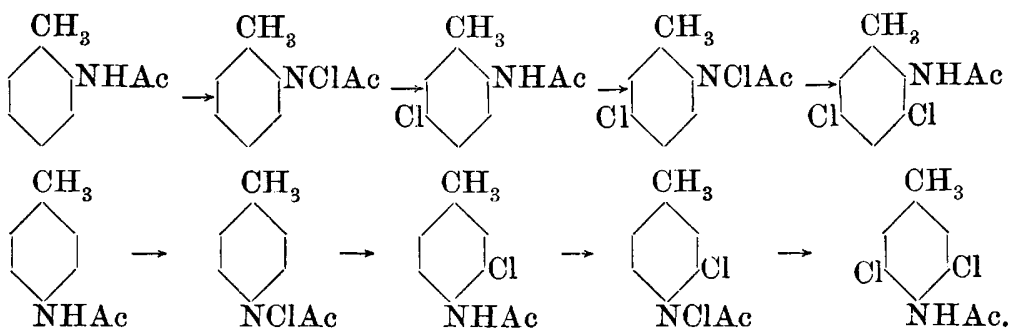

The bromine derivatives behave in a precisely similar manner. As with the substituted anilides, when the ortho- and para-positions to the acetylchloramino-group are occupied no further isomeric change takes place, hydrolysis or decomposition resulting from attempts to induce it.

The behaviour of the nitrogen chlorides and bromides derived from the toluidides is in entire agreement with the conclusion that substitution by chlorine or bromine in anilines and anilides is not a direct process, but a result of the transformation of a nitrogen chloride or bromide. The degree of ease or difficulty with which substitution in the toluidines and toluidides can be directly effected corresponds completely with the ease or difficulty with which the transformation of the corresponding nitrogen chloride or bromide can be brought about.

For example, $o$ - and $p$-acetotoluidide can be converted into the monobromotoluidides with the greatest ease, and in agreement with this the corresponding nitrogen bromides are also transformed quantitatively.

On the other hand, the action of chlorine on $p$-acetotoluidide or bromine on 3-bromo- $p$-acetotoluidide yields tarry products, from which only with the greatest difficulty 3-chloro-p-acetotoluidide, or 3:5-dibromo-p-acetotoluidide, in small amount, can be isolated. Corresponding with this we find that the isomeric nitrogen chloride and bromide can only be transformed with great difficulty, a large part, under condi- 
tions which affect the isomerisation, undergoing a more complicated change.

The properties of these nitrogen chlorides and bromides resemble exactly those of other members of the class (Trans., 1899, 75, 1046 ; 1900, 77, 134; Ber., 1899, 32, 3573). The nitrogen chlorides are colourless, the nitrogen bromides sulphur-yellow solids all crystallising well in modifications of four-sided prisms, terminated by domes.

\section{o-Acetylchloraminotoluene (o-Tolyl Acetyl Nitrogen Chloride), $\mathrm{CH}_{3} \cdot \mathrm{C}_{6} \mathrm{H}_{4} \cdot \mathrm{NCl} \cdot \mathrm{CO} \cdot \mathrm{CH}_{3}$.}

Powdered $o$-acetotoluidide is shaken with excess of $\mathrm{N} / 2$ potassium hypochlorite containing potassium hydrogen carbonate. In a short time, a limpid, faintly yellow oil separates. This is dissolved in light petroleum (b. p. $50-80^{\circ}$ ), and from the solution the nitrogen chloride crystallises in star-shaped clusters of short, flattened prisms or plates melting at $43^{\circ}$.

$0 \cdot 1616$ liberated $\mathrm{I}=17 \cdot 72$ c.c. $N / 10$ iodine. $\mathrm{Cl}$, as $: \mathrm{NCl},=19 \cdot 44$. $\mathrm{C}_{9} \mathrm{H}_{10} \mathrm{ONCl}$ requires $\mathrm{Cl}$, as $: \mathrm{NCl},=19 \cdot 31$ per cent.

This nitrogen chloride is extremely soluble in chloroform or benzene, and fairly soluble in light petroleum. On heating to $160^{\circ}$, sudden action occurs, the compound being mainly transformed into 5-chloro$o$-acetotoluidide; the conversion, however, is accompanied by partial decomposition.

The isomeric change takes place slowly but quantitatively, when a solution of the nitrogen chloride in glacial acetic acid is kept at a temperature of $35-40^{\circ}$, about 36 hours being required for its completion. If a drop of concentrated sulphuric acid is added to the solution, the conversion is complete in a few minutes. A quick transformation is also brought about when the nitrogen chloride is placed in rapidly boiling water, but under these conditions $20-30$ per cent. undergoes hydrolysis. A search was made for 3-chloro-o-acetotoluidide in the product of the transformation, but its presence could not be detected. o-Tolyl acetyl nitrogen chloride is comparatively stable, and can be kept for weeks in the absence of moisture without change.

\section{o-Acetylchloramino-5-chlorotoluene (5-Chloro-o-tolyl Acetyl Nitrogen Chloride), $\mathrm{CH}_{3} \cdot \mathrm{ClC}_{6} \mathrm{H}_{3} \cdot \mathrm{NCl} \cdot \mathrm{CO} \cdot \mathrm{CH}_{3}$.}

This nitrogen chloride is easily prepared by agitating 5-chloro-o-acetotoluidide with a slight excess of $N / 2$ bleaching powder solution just acidified with acetic acid. The compound is extremely soluble in chloroform or benzene, but only moderately soluble in acetic acid. It crystallises from light petroleum in short 4- or occasionally 6 -sided prisms frequently terminated by domes, and melts at $66^{\circ}$. 
0.2154 liberated $I=19 \cdot 9$ c.c. $N / 10$ iodine. $\mathrm{Cl}$, as $: \mathrm{NCl},=16 \cdot 38$. $\mathrm{C}_{9} \mathrm{H}_{9} \mathrm{ONCl}_{2}$ requires $\mathrm{Cl}$, as $: \mathrm{NCl},=16 \cdot 26$ per cent.

When dissolved in glacial acetic acid, this nitrogen chloride undergoes transformation only very slowly at the ordinary temperature; but on boiling the solution for one hour it entirely changes into $3: 5$-dichloro-o-acetotoluidide (m. p. $185^{\circ}$ ).

Claus and Stapelberg (Annalen, 1893, 274, 291) prepared 3:5-dichloro-o-acetotoluidide by chlorinating $o$-acetotoluidide dissolved in alcohol and acetic acid. We find it far preferable to add gradually an excess of bleaching powder solution to one part of 0 -acetotoluidide dissolved in 5 parts of glacial acetic acid at the ordinary temperature, by which operation the nitrogen chloride of 5-chloro-0-acetotoluidide is formed. The latter is then separated, and heated with acetic acid until transformation is complete, when a nearly quantitative yield is obtained.

\section{o-Acetylchloramino-3 : 5-dichlorotoluene (3 : 5-Dichloro-o-tolyl Acetyl Nitrogen Chloride), $\mathrm{CH}_{3} \cdot \mathrm{C}_{6} \mathrm{H}_{2} \mathrm{Cl}_{2} \cdot \mathrm{NCl} \cdot \mathrm{CO} \cdot \mathrm{CH}_{3}$.}

To prepare this compound, a solution of the $3: 5$-dichloro-o-acetotoluidide in acetic acid is treated with excess of $N / 2$ bleaching powder solution at the ordinary temperature. The nitrogen chloride which separates as an oil is crystallised from light petroleum, in which it is very soluble. It forms short four-sided prisms, frequently with domed ends, and melts at $78^{\circ}$.

$0 \cdot 2037$ liberated $I=16 \cdot 1$ c.c. $N / 10$ iodine. $\quad \mathrm{Cl}$, as $: \mathrm{NCl},=14 \cdot 01$. $\mathrm{C}_{9} \mathrm{H}_{8} \mathrm{ONCl}_{3}$ requires $\mathrm{Cl}$, as $: \mathrm{NCl},=14.04$ per cent.

\section{p-Acetylchloraminotoluene (p-Tolyl Acetyl Nitrogen Chloride), $\mathrm{CH}_{3} \cdot \mathrm{C}_{6} \mathrm{H}_{4} \cdot \mathrm{NCl} \cdot \mathrm{CO} \cdot \mathrm{CH}_{3}$.}

This substance is prepared similarly to the corresponding orthoderivative. To ensure complete conversion after treatment of the $p$-acetotoluidide with hypochlorous acid, it is best to dissolve the product in chloroform and to shake the liquid two or three times with a fresh solution of hypochlorous acid. It crystallises exceedingly well from light petroleum or from a mixture of this and chloroform in short, lustrous, four-sided prisms, which are often flattened or rhombic in appearance, and melts at $91-92^{\circ}$.

$0 \cdot 1524$ liberated $\mathrm{I}=16 \cdot 5$ c.c. $N / 10$ iodine. $\mathrm{Cl}$, as $: \mathrm{NCl},=19 \cdot 20$. $\mathrm{C}_{9} \mathrm{H}_{10} \mathrm{ONCl}$ requires $\mathrm{Cl}$, as $: \mathrm{NCl},=19 \cdot 31$ per cent.

This nitrogen chloride when pure can be kept for months in a dry atmosphere and may even be heated to $175^{\circ}$ without suffering any decomposition. If slightly impure or moist, it reddens on keeping, 
and on heating decomposes rapidly even at $100^{\circ}$ with development of colour and evolution of gas. Dissolved in chloroform, light petroleum, or acetic acid, it completely decomposes at the ordinary temperature in two or three days, and in an hour or so when warmed, with the formation of 3-chloro- $p$-acetotoluidide, $p$-acetotoluidide, and a red, oily substance. Heated in the presence of water, similar actions take place, and an amount of hydrochloric acid is liberated corresponding to about 14 per cent. of the nitrogen chloride used. When a few grams of the nitrogen chloride are decomposed by warming with acetic acid, to which two or three drops of sulphuric acid have been added, or by adding the powdered solid to boiling water, from 50-60 per cent. is transformed into 3-chloro- $p$-acetotoluidide. With larger quantities, however, the yield is much less and the chlorotoluidide difficult to purify. The behaviour of this nitrogen chloride accounts for the difficulties experienced by Lellmann and Klotz (Annalen, 1885, 231, 311) in preparing 3-chloro-p-acetotoluidide by direct chlorination of $p$-acetotoluidide dissolved in acetic acid. They were only able to obtain a 20 per cent. yield, and did not succeed in discovering the cause of this unsatisfactory result. We have reason to believe that a secondary reaction takes place, in which the methyl group interacts with the chlorine attached to the nitrogen.

Preparation of 3-Chloro-p-toluidine.-The following method gives a 50 per cent. yield of 3-chloro-p-toluidine from $p$-acetotoluidide.

Fifty grams of $p$-acetotoluidide are dissolved in 200 c.c. of glacial acetic acid and a small excess of $N / 2$ bleaching powder solution added. Heat is evolved and a reddish oil separates, which solidifies on cooling. The dark red mass, which largely consists of 3-chloro- $p$-toluidide and $p$-acetotoluidide is boiled with alcohol and sulphuric acid. The acid is then partially neutralised and the still acid product distilled in steam. 3.Cbloro-p-toluidine comes over first, and, after completely neutralising the acid, is followed by $p$-toluidine, which represents about 15 per cent. of the original $p$-acetotoluidide. A dark, oily substance remains in the distilling flask.

\section{p-Acetylchloramino-3-chlorotoluene (3-Chloro-p-tolyl Acetyl Nitrogen Chloride), $\mathrm{CH}_{3} \cdot \mathrm{C}_{6} \mathrm{H}_{3} \mathrm{Cl} \cdot \mathrm{NCl} \cdot \mathrm{CO} \cdot \mathrm{CH}_{3}$.}

3-Chloro- $p$-acetotoluidide is dissolved in acetic acid and a slight excess of $N / 2$ bleaching powder solution added. The oil which forms is separated, shaken with sodium hydrogen carbonate to remove acetic acid, and then recrystallised from light petroleum. It forms very short, flattened prisms, which frequently appear as diamond-shaped plates, and melts at $48^{\circ}$.

0.3167 liberated $\mathrm{I}=29 \cdot 3$ c.c. $N / 10$ iodine. $\mathrm{Cl}$, as $: \mathrm{NCl},=16 \cdot 35$. $\mathrm{C}_{9} \mathrm{H}_{9} \mathrm{ONCl}_{2}$ requires $\mathrm{Cl}$, as $: \mathrm{NCl},=16 \cdot 26$ per cent. 
This nitrogen chloride, dissolved in glacial acetic acid, is transformed very slowly at the ordinary temperature into $3: 5$-dichloro- $p$-acetotoluidide. On boiling such a soluiion, a brilliant red colour develops and no nitrogen chloride remains after some fifteen minutes; on cooling, long needles of the dichlorotoluidide separate, but the yield does not amount to more than 50 per cent. of the theoretical.

\section{p-Acetylchloramino-3 :5-dichlorotoluene (3:5-Dichloro-p-tolyl Acetyl Nitrogen Chloride), $\mathrm{CH}_{3} \cdot \mathrm{C}_{6} \mathrm{H}_{2} \mathrm{Cl}_{2} \cdot \mathrm{NCl} \cdot \mathrm{CO} \cdot \mathrm{CH}_{3}$.}

This substance is prepared from the corresponding dichlorotoluidide exactly as the last, and is recrystallised from light petroleum. It forms thin, four-sided prisms, often $4-5$ centimetres long, and melts at $72^{\circ}$.

$$
\begin{gathered}
0.1228 \text { liberated } \mathrm{I}=9 \cdot 6 \text { c.c. } N / 10 \text { iodine. } \mathrm{Cl} \text {, as }: \mathrm{NCl},=13 \cdot 86 . \\
\mathrm{C}_{9} \mathrm{H}_{8} \mathrm{ONCl}_{3} \text { requires } \mathrm{Cl} \text {, as }: \mathrm{NCl},=14 \cdot 04 \text { per cent. }
\end{gathered}
$$

\section{o-Acetylbromaminotoluene (o-Tolyl Acetyl Nitrogen Bromide), $\mathrm{CH}_{3} \cdot \mathrm{C}_{2} \mathrm{H}_{4} \cdot \mathrm{NBr} \cdot \mathrm{CO} \cdot \mathrm{CH}_{3}$}

This compound is obtained by treating finely divided $o$-acetotoluidide suspended in a dilute solution of potassium hydrogen carbonate with a slight excess of a solution of hypobromous acid, keeping the temperature below $0^{\circ}$. Action takes place rapidly, the toluidide losing its crystalline form and becoming pale yellow in colour. The nitrogen bromide can be crystallised from a mixture of chloroform and light petroleum, from which it separates as pale yellow, four-sided plates melting at $100.5^{\circ}$. It is readily soluble in chloroform or benzene, but only slightly so in light petroleum.

$0 \cdot 2530$ liberated $\mathrm{I}=22 \cdot 25 \mathrm{~N} / 10$ iodine. $\mathrm{Br}$, as $: \mathrm{NBr},=35 \cdot 16$.

$\mathrm{C}_{9} \mathrm{H}_{2 n} \mathrm{ONBr}$ requires $\mathrm{Br}$, as $: \mathrm{NBr},=35 \cdot 07$ per cent.

This nitrogen bromide, on rapidly heating, melts sharply at $100.5^{\circ}$, but on keeping about 10 seconds at this temperature transformation takes place, accompanied by evolution of heat, and the whole solidifies to a slightly brown, crystalline mass of 5-bromo-o-acetotoluidide, which melts only a few degrees below $160^{\circ}$. ${ }^{*}$ This transformation takes place very readily if the compound is heated under water, or still better if it is dissolved in glacial acetic acid and the solution allowed to stand at the ordinary temperature for 24 hours. The transformation appears to be quantitative; we have never observed the formation of any other product.

* 5-Bromo-o-acetotoluidide, when pure, melts sharply at $160^{\circ}$, not at $156-157^{\circ}$, as usually given. 


\section{o-Acetylbromamino-5-bromotoluene (5-Bromo-o-tolyl Acetyl Nitrogen Bromide), $\mathrm{CH}_{3} \cdot \mathrm{C}_{6} \mathrm{H}_{3} \mathrm{Br} \cdot \mathrm{NBr} \cdot \mathrm{CO} \cdot \mathrm{CH}_{3}$.}

This nitrogen bromide was prepared exactly as above, but to ensure complete conversion, the product, which clots together, was dissolved in chloroform and the solution thoroughly shaken with more hypobromous acid containing potassium hydrogen carbonate. The solid, obtained by evaporating off the chloroform, was recrystallised from chloroform and light petroleum. The crystals are brilliant yellow, apparently rectangular, plates melting at $91^{\circ}$.

0.3852 liberated $\mathrm{I}=25 \cdot 1$ c.c. $N / 10$ iodine. $\mathrm{Br}$, as $: \mathrm{NBr},=26.05$. $\mathrm{C}_{9} \mathrm{H}_{9} \mathrm{ONBr}_{2}$ requires $\mathrm{Br}$, as $: \mathrm{NBr},=26.05$ per cent.

When 2-methyl-4-bromophenyl acetyl nitrogen bromide is heated above its melting point at about $110-120^{\circ}$, it darkens somewhat in colour and is transformed into the isomeric 3:5-dibromo-o-acetotoluidide, this then slowly solidifies to a light brown, crystalline mass, which melts not very sharply at about $170^{\circ}$. A certain amount of decomposition always accompanies the transformation, this being more marked the more rapid the heating.

This isomeric change takes place readily when the nitrogen bromide is heated with water at $100^{\circ}$, although here a certain amount of hydrolysis accompanies it, or when the compound is heated at $100^{\circ}$ with glacial acetic acid in a sealed tube. On recrystallising the product, $3: 5$-dibromo-o-acetotoluidide is obtained in long, colourless needles which melt at $205^{\circ}$.

\section{o-Acetylbromamino-3 : 5-dibromotoluene (3 :5-Dibromo-o-tolyl Acetyl Nitrogen Bromide), $\mathrm{CH}_{3} \cdot \mathrm{C}_{6} \mathrm{H}_{2} \mathrm{Br}_{2} \cdot \mathrm{NBr} \cdot \mathrm{CO} \cdot \mathrm{CH}_{3}$.}

3 : 5-Dibromo-o-acetotoluidide is also readily converted as above by hypobromous acid into its nitrogen bromide, which crystallises well from petroloum (b. p. $80-100^{\circ}$ ) in characteristic brilliant yellow, four-sided plates melting at $120^{\circ}$.

0.4526 liberated $\mathrm{I}=23.25$ c.c. $N / 10$ iodine. $\mathrm{Br}$, as $: \mathrm{NBr},=20.54$. $\mathrm{C}_{9} \mathrm{H}_{8} \mathrm{ONBr} \mathrm{r}_{3}$ requires $\mathrm{Br}$, as $: \mathrm{NBr},=20.72$ per cent.

\section{p-Acetylbromaminotoluene (p-Tolyl Acetyl Nitrogen Bromide), $\mathrm{CH}_{3} \cdot \mathrm{C}_{6} \mathrm{H}_{4} \cdot \mathrm{NBr} \cdot \mathrm{CO} \cdot \mathrm{CH}_{3}$.}

$p$-Acetotoluidide in a finely divided state was suspended in a very weak solution of potassium hydrogen carbonate containing ice, about one and a-half times the theoretical quantity of a solution of hypobromous acid cooled below $0^{\circ}$ added quickly, and the whole stirred for a few 
minutes. The pale yellow product was then crystallised from a mixture of chloroform and light petroleum.

$p$-Tolyl acetyl nitrogen bromide forms brilliant yellow, four-sided prisms terminated by domes, one side of the latter being very largely developed. It is extremely unstable; exposed to the moist air of a laboratory, it becomes in a few minutes of a pale pink colour, which deepens on standing to a full red, whilst the melting point continuously falls. The crystals can, however, be kept in an exhausted desiccator for several hours without change.

0.3059 liberated $\mathrm{I}=26.9$ c.c. $N / 10$ iodine. $\mathrm{Br}$, as $: \mathrm{NBr},=35 \cdot 15$. $\mathrm{C}_{9} \mathrm{H}_{10} \mathrm{ONBr}$ requires $\mathrm{Br}$, as $: \mathrm{NBr},=35.07$ per cent.

On heating quickly it melts at $94-95^{\circ}$ to a pale yellow liquid, but at this temperature rapid transformation into 3-bromo-p-acetotoluidide goes on, and in a few seconds the melted mass crystallises. Transformation also takes place quickly at a lower temperature; when heated at $50^{\circ}$ for a few minutes the crystals slowly liquefy and resolidify to a pale pink, crystalline mass, which again melts only $2-3^{\circ}$ below the melting point of the $p$-bromotoluidide. This isomeric change goes on slowly at the ordinary temperature, and even to a considerable extent below $0^{\circ}$. When the nitrogen bromide is warmed with water, or dissolved in chloroform or glacial acid, and the solution allowed to stand for a few hours, complete transformation takes place and the change is practically quantitative, although a pale pink colour is developed. Pure 3-bromo $p$-acetotoluidide can be obtained in long, white prisms by once crystallising the transformation product from alcohol. The behaviour of this nitrogen bromide offers a marked contrast to that of the corresponding nitrogen chloride.

\section{p-Acetylbromamino-3-bromotoluene (3-Bromo-p-tolyl Acetyl Nitrogen} Bromide), $\mathrm{CH}_{3} \cdot \mathrm{C}_{6} \mathrm{H}_{3} \mathrm{Br} \cdot \mathrm{NBr} \cdot \mathrm{CO} \cdot \mathrm{CH}_{3}$.

This was prepared in the ordinary way by the action of hypobromous acid on 3-bromo-p-acetotoluidide, and was crystallised from a mixture of chloroform and light petroleum. It forms pale yellow, four-sided plates which melt at $87^{\circ}$.

0.2745 liberated $\mathrm{I}=17.9$ c.c. $N / 10$ iodine. $\mathrm{Br}$, as $: \mathrm{NBr},=26.07$. $\mathrm{C}_{9} \mathrm{H}_{9} \mathrm{ONBr}_{2}$ requires $\mathrm{Br}$, as $: \mathrm{NBr},=26.05$ per cent.

On heating above its melting point, it decomposes between $100^{\circ}$ and $110^{\circ}$, yielding a red, tarry product which does not crystallise. A similar viscous substance is formed when the nitrogen bromide is heated at $100^{\circ}$ in a sealed tube with a little glacial acetic acid. The product is soluble in alcohol or acetic acid, but a thick yellow oil is deposite $d$ 
on cooling. If this is removed from time to time and the solution boiled with animal charcoal, $3: 5$-dibromo-p-acetotoluidide (m. p. 206 ) finally crystallises out ; the yield of the latter, however, is only about 10 per cent. of the theoretical. In this action, the normal transformation of the nitrogen bromide into the isomeric bromotoluidide is complicated by another action in which the methyl group is probably attacked by the bromine attached to the nitrogen.

The extent to which the latter action takes place when the nitrogen chlorides and bromides derived from the toluidides undergo the normal isomeric change apparently depends on the relative difficulty with which transformation takes place. When isomeric change occurs readily and at a low temperature as with $o$ - and $p$-tolyl acetyl nitrogen bromides, this is practically the sole action; when, however, it cannot be easily effected, and only at a relatively high temperature, it is accompanied by the other reaction.

\section{p-Acetylbromamino-3:5-dibromotoluene (3:5-Dibromo-p-tolyl Acetyl Nitrogen Bromide), $\mathrm{CH}_{3} \cdot \mathrm{C}_{6} \mathrm{H}_{2} \mathrm{Br}_{2} \cdot \mathrm{NBr} \cdot \mathrm{CO} \cdot \mathrm{CH}_{3}$.}

3:5-Dibromo-p-acetotoluidide (m. p. 206 ${ }^{\circ}$ ) also easily yields a nitrogen bromide on treatment with hypobromous acid. To ensure complete conversion, it is best to dissolve the product in chloroform, and then to stir or shake thisfor an hour or so with excess of a fresh solution of hydrobromous acid containing a little potassium hydrogen carbonate. On evaporating off the chloroform or adding light petroleum, the nitrogen bromide separates in brilliant, yellow, short, four-sided prisms terminated by domes and melts at $118^{\circ}$.

0.3929 liberated $\mathrm{I}=20.2$ c.c. $N / 10$ iodine. $\mathrm{Br}$, as $: \mathrm{NBr},=20.55$. $\mathrm{C}_{9} \mathrm{H}_{8} \mathrm{ONBr}_{3}$ requires $\mathrm{Br}$, as $: \mathrm{NBr},=20.72$ per cent.

\section{Method of Transforming Nitrogen Chlorides and Bromides.}

The transformation of nitrogen chlorides and bromides is generally best effected by allowing a solution in a little glacial acetic acid to stand at the ordinary temperature, or, when necessary, heating it in a sealed tube. Acetic anhydride may occasionally be employed as solvent when the substances are hydrolysed exceptionally readily, as is the case with some nitrogen bromides. Addition of a drop of sulphuric acid is in some cases advantageous, as in the transformation of the nitrogen chloride of $p$-acetotoluidide. With the more readily transformable compounds, heating under water is sufficient, although this generally causes some hydrolysis.

Chamical Laboratory,

St. Bartholomew's Hospital and College, E.C. 